\begin{tabular}{c} 
Benha Veterinary Medical Journal \\
$\begin{array}{c}\text { Official Jounnal Issued by } \\
\text { Feculty of } \\
\text { Veterinary Medicine }\end{array}$ \\
\hline
\end{tabular}

Original Paper

\title{
Investigation of the effects of copper deficiency on fertility and some hematobiochemical parameters in rams with trial for treatment
}

\author{
Halla A. El Said ${ }^{1, *}$, Ghada M. El Khder'1, Ehab M. Hussein'1, Nagwa A. Helmy², Mona Salah El Deen ${ }^{3}$ \\ ${ }^{1}$ Biochemistry, ${ }^{2}$ Parasitology and ${ }^{3}$ Clinical Pathology Departments, Animal Health Research Institute - Zagazig Branch, Egypt
}

\section{ARTICLE INFO}

\begin{tabular}{l}
\hline Keywords \\
Copper \\
Hematobiochemical \\
Ram \\
Semen \\
\hline
\end{tabular}

Received 30/09/2019

Accepted 10/12/2019

Available On-Line

$12 / 05 / 2020$

\begin{abstract}
Fecal and blood samples were collected from 80 rams (50 suffering from unthriftness, weakness, diarrhea, recumbency of some rams, and 30 healthy ram) from private farms at Abo Hamad city, Sharkia Governorate for parasitological examination and estimation of copper level in blood. After parasitological examination 15 rams were divided into three equal groups. $1^{\text {st }}$ group healthy rams was free from any parasites with normal copper level (control), $2^{\text {nd }}$ group rams was suffering from previous signs with low copper level not treated, $3^{\text {rd }}$ group rams was suffering from previous signs with low copper level treated with $1 \mathrm{gm}$ copper sulphate/liter drinking water for one month. At $1^{\text {st }}, 15^{\text {th }}$ and $30^{\text {th }}$ day post treatment blood and semen samples were collected from each ram for study hematobiochemical parameters and semen character. Parasitological examination of faecal samples revealed presence of parasites eggs in 11 healthy rams (6 single infection - 5 mixed infection) beside presence parasites eggs in 20 hypocuprotic rams (11 single infection - 9 mixed infection). Examination of rams with hypocupriosis revealed significant decrease in erythrocytic count, hemoglobin, packed cell volume \%, leukocytic count, total protein, albumin, globulin, copper, selenium, zinc, iron, testosterone, triiodothronine, thyroxin, sperm count, sperm motility beside insignificant reduction in ejaculate volume and significant elevation in asprtate aminotransferase, alanine aminotransferase and alkaline phosphatase, urea, creatinine, dead sperm, sperm abnormality. Improvement of hematobiochemical and semen parameters was observed at $1^{\text {st }}$ day post treatment with copper sulphate. It could be concluded that copper deficiency affects male fertility and hematobiochemical parameters, copper sulphate is effective in ameliorating adverse effect of copper deficiency in rams.
\end{abstract}

\section{INTRODUCTION}

* Corresponding author Halla A. El Said. Biochemistry Department, Animal Health Research Institute - Zagazig Branch,

Egypt. E-mail address: hallaelsaid@yahoo.com

Reproductive disorders and malnutrition are the main problems that determine productivity in rams. Nutritional deficiency either major or minor minerals affects metabolic and enzymatic functions Nutritional deficiency is either primary caused by a lake of mineral in diet or secondary resulting from factors that interfere with absorption or utilization(Radostits et al., 2003).

Internal parasites are major contributors to reduced body performance and productivity in sheep and goats all over the world. Parasitic infestation induced deficiency of trace element as copper. The clinical signs of parasitic infestation vary depending on parasite species and abundance (Waller and Thamsborg, 2004). The largest health threat to sheep is the Haemonchus contortus parasite, commonly referred to as barber pole worm (Aphzal et al., 2010). Gastro-intestinal nematode infections as mixed or single infections are major parasitic conditions influe-ncing the sheep and goat industry in both tropical and temperate climates (Faizal and Rajapakse, 2001).

Copper is a vital micronutrient in all living organisms found in a wide variety of tissues in human and animal bodies. Copper is essential for several variety of bio-chemical processes in the body to operate normally, so it must be a part of the diet (Shahin, 2012). Copper plays a part in the activity of more than 20 metalloen-zymes, cofactors, and metalloproteins that are connected with destruction of free radicals and synthesis of connective tissues (Ortolani et al., 2003). Semen is containing a variety of minerals (Marzec et al., 2012). Trace elements play a role in male reprodu-ction as unbalance in their amounts lead to defective Spermatogenesis, reduced libido, and impairment male fertility (Tvrdá et al., 2013). Abnormal levels of copper affect sperm production (Cheah and Yang 2011). Disturbances in copper absorption may have a negative

\footnotetext{
* Corresponding author Halla A. El Said. Biochemistry Department, Animal Health Research Institute - Zagazig Branch

Egypt. E-mail address: hallaelsaid@yahoo.com
} 
impact on sperm viability and morphology (Knazicka et al., 2012). Deficiency of copper is associated with impaired reproductive performance and subnormal fertility (Radostits et al., 2000).

This investigation was carried out for studying relationship between copper deficiency and male fertility and some hematobiochemical parameters in rams.

\section{MATERIAL AND METHODS}

\section{Fecal samples}

About 80 fecal samples were collected from rams (50 suffering from unthriftiness, off food, weakness, diarrhea, recumbency of some of rams and 30 fecal samples from healthy rams) from private farm at Abo Hamad city, Sharkia Province for parasitological examination. Fecal samples were transported to laboratory where examined. Sedimentation and floatation technique (Soulsby, 1982) were used to detect the presence of eggs of nematodes in samples. Degree of infestation was determined by counting egg/gram faeces through MC Master Technique (Moning, 1963).Copper sulphate is a yellow powder mixture obtained from El Nasr Company for drug and chemical, Egypt.

\section{Animals}

After parasitological examination 15 rams free from internal and external parasite were used in this investigation (5 rams healthy and copper level (115.86 \pm 3.16$)-10$ rams were suffering from off food, weakn-ess, continuous diarrhea, recumbency of some rams and low copper $(89.42 \pm 2.41)$ were used in this study.

\section{Experimental design}

Rams were divided into 3 equal groups. $1^{\text {st }}$ group include 5 rams were healthy free from internal and external parasites and normal copper levels not treated (control group), $2^{\text {nd }}$ group include -ve hypocuprotic rams that were free from internal and external parasite and were not treated. $3^{\text {rd }}$ group include 5 hypocuprotic rams that were free from internal and external parasite and were treated with $1 \mathrm{gm}$ copper sulphate /liter in drinking water for one month.

\section{Blood samples}

At $1^{\text {st }}, 15^{\text {th }}$ and $30^{\text {th }}$ days post treatment, two blood samples were collected from all rams. First sample was taken in a tube contain EDTA for estimation of blood picture Jain (1986). Second sample was centri-fuged to obtain clear serum for estimation Selenium, copper, iron and zinc using atomic absorption spectro-photometer (Sunderman and Roszel 1967). Testosterone, triiodothyronine and thyroxine by radioimmunoassay (Abraham 1981), total proteins (Doumas, et al. 1981), albumin (Drupt, 1974), globulin were calculated as difference between total proteins and albumin, asprtate aminotransferase and alanine aminotransferase (Reitman and Frankel, 1957) alkaline phosphatase (John, 1982) urea and creatinine (Doumas and Biggs, 1972).

\section{Examination of semen sample}

Semen samples were collected from all rams using artificial vagina at periods to estimate sperm picture (Bearden and Fluquary, 1980)

\section{Statistical analysis}

The obtained data was analyzed by using computerized SPSS program version 25 according (Tambane and Dunlop 2000). The level of significance was set at $p<0.05$.

\section{RESULTS}

Clinical signs appeared on hypocuprosis rams were unthriftness, off food, emaciation, weakness, recumba-ncy of some rams and low serum copper

Parasitological examination of fecal samples revealed presence of eggs as single infection 11 healthy rams (2 Haemonchus contortus, 3 Cooperia spp., 1 Fasciola spp) Beside 5 mixed (3 Cooperia spp + Fasciola spp, 2 Trichuris + Cooperia spp.+Haemonchus contortus) however, examination 20 rams with hypocopiosis revealed presence of either single infection (2 sample Coopered spp., 3 Trichuris, 4 Ostetagia circumcieta, 2 fasciola spp), mixed (2 Trichuris+ Fasciola spp, 4 Haemonchus contortus+ Ostetagia, 3 Cooperia spp. + Fasciola spp+Trichuris (tables 1 and 2).

Hypocupritic rams revealed significant decrease in RBCs, $\mathrm{Hb}, \mathrm{PCV} \%$ and WBCs (table 3 ).

Copper deficiency induced significant reduction in total protein, albumin and globulin beside elevation in AST,ALT, ALP, creatinine and urea (table 4).

Rams suffering from copper deficiency showed signif-icant decrease in selenium, zinc, iron, testosterone, triiodothyronin, thyroxin (table 5 and 6).

Hypocupritic rams showed significant decrease in sperm cell concentration, individual motility beside insignificant reduction in ejaculate volume coupled with significant elevation in dead sperm and sperm abnormality (table 7). Improvement of hematobiochemical and semen parameters was observed at $1^{\text {st }}$ day post treatment with copper sulphate.

Table 1 Parasitological examination of collected fecal samples.

\begin{tabular}{llllll}
\hline & \multirow{2}{*}{ Number of faecal samples } & \multicolumn{2}{c}{ Positive samples } & \multicolumn{2}{c}{ Negative samples } \\
& & No & $\%$ & No & $\%$ \\
\cline { 2 - 6 } Diseased rams & 50 & 27 & 54 & 23 & 46 \\
Healthy rams & 30 & 15 & 50 & 15 & 50 \\
\hline
\end{tabular}

Table 2 Type of infestation in collected fecal samples

\begin{tabular}{|c|c|c|c|c|c|c|c|}
\hline \multirow[b]{2}{*}{ Animals } & \multicolumn{4}{|l|}{ Single infestation } & \multicolumn{3}{|l|}{ Mixed infestation } \\
\hline & Type of parasite & Egg count/gm faeces & \multicolumn{2}{|l|}{ Rams } & Type of parasite & \multicolumn{2}{|c|}{ Rams } \\
\hline \multirow{4}{*}{ Diseased } & Cooperia spp. & 210 & 3 & & Trichuris+ F. spp. & 2 & \multirow{4}{*}{9} \\
\hline & Trichuris & 150 & 5 & & H. contortus+ $\mathrm{O}$. circumcieta & 4 & \\
\hline & O.circumcieta & 563 & 5 & 18 & Cooperia spp. + F. Spp. + Trichuris & 3 & \\
\hline & Fasciola spp. & 315 & 5 & & & & \\
\hline \multirow{3}{*}{ Healthy } & H. contortus & 830 & 4 & \multirow{3}{*}{10} & Cooperia spp+ Fasciola spp. & 3 & \multirow{3}{*}{5} \\
\hline & Cooperia spp. & 130 & 3 & & Trichuris + Cooperia spp.+ & 2 & \\
\hline & Fasciola spp. & 137 & 3 & & H. contortus & 2 & \\
\hline
\end{tabular}


Table 3 Effect of hypocuprosis on blood picture in rams $(n=5)$

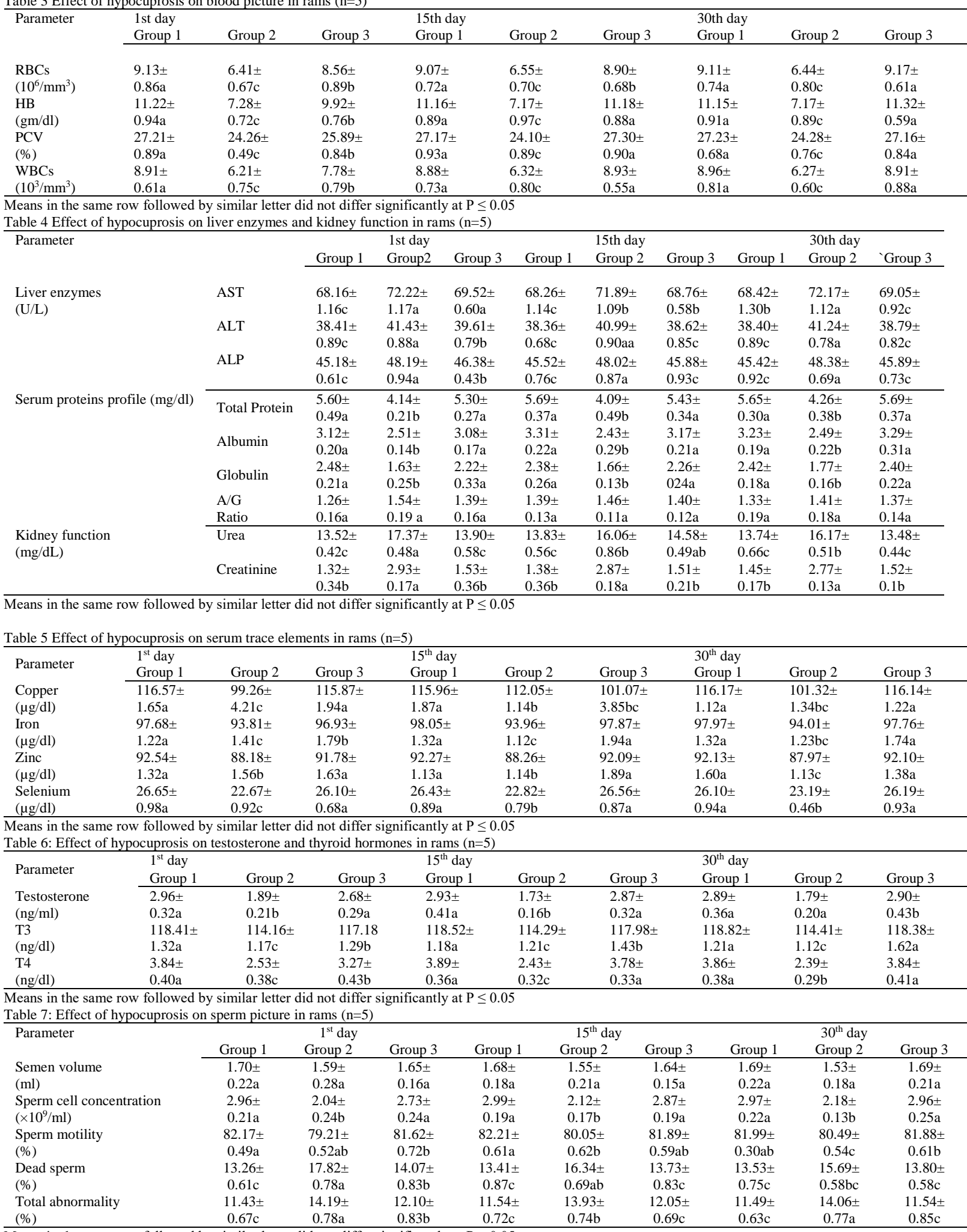

Means in the same row followed by similar letter did not differ significantly at $\mathrm{P} \leq 0.05$ 


\section{DISCUSSION}

Parasitological examination of fecal samples revealed presence of eggs as single infection 11 healthy rams (2 Haemonchus contortus, 3 Cooperia spp., 1 Fasciola spp) Beside 5 mixed (3 Cooperia spp + Fasciola spp, 2 Trichuris + Cooperia spp.+Haemonchus contortus) however, examination 20 rams with hypocopiosis revealed presence of either single infection (2 sample Coopered spp., 3 Trichuris, 4 Ostetagia circumcieta, 2 fasciola spp) or mixed (2 Trichuris+ Fasciola spp, 4 Haemonchus contortus+ Ostetagia, 3 Cooperia spp. + Fasciola spp+Trichuris. The obtained results in this study are agreed with Schwan, et al. (1987) who detects Trichuris, Haemonchus contortus and Fasciola spp in sheep with copper deficiency. Same parasites were found in faeces of unthrifty sheep (Fouda, et al., 2005). In the present study, the main clinical signs appeared on hypocuprosis in rams were off food, unthriftness, weakness, continuous diarrhea and recumbency of some rams. This clinical signs in animals suffering from hypocuprosis may be due to importance of copper in tissue oxidation and metabolism (Radostits, et al. 2003). Same clinical signs were observed by Dosm et al. (2006) in kids suffering from copper deficiency and Naylor, et al. (2015) in hypocuprotic sheep.

The present work revealed that hypocuprotic rams showed significant reduction in erythrocytic count, hemoglobin, packed cell volume $\%$ and leukocytic count. Reduction in erythrocytic count in hypocu-protic animal is due to depression of erythrogenesis (Coles, 1986).

Change in blood picture may be due to deficiency of copper which acts as a catalyst in the production of hemoglobin and facilitates the absorption of iron and formation of new erythrocyte (Osman, et al. 1991). Similar trend was reported by Christopher (1992) who stated that hypochromic micro-cytic anemia occurs in advanced stage of hypocuprosis due to impaired uptake of iron and failure of hemoglobin formation. Deficiency of copper leads to failure of bone marrow to produce erythrocyte (Ralph and Mcardle, 2001). The obtained data revealed that, rams suffering from copper deficiency showed elevation in liver enzymes (AST, ALT and ALP) urea and creatinine. Our data were correlated with Ahmed, et al. (2009) reported that copper deficiency induced increase in AST, ALT, ALP, urea and creatinine. Similar results were previously reported by Abd Elghany, et al. (2015) and Tikoo, et al. (2018) who recorded that copper deficiency induced increase liver enzymes, urea and creatinine

Our findings revealed that copper deficiency in rams evoked significant decrease in total proteins, albumin and globulin. Reduction in protein picture in our study may be due to anorexia due to copper deficiency. Hypocuprosis induced significant decrease in serum total protein, albumin and globulin due to mal absorption of dietary content from intestinal tract in diarrheic animals (Coles, 1986). Our results were agreed with Shahin (2012) stated that copper deficiency produced significant reduction in blood total protein, albumin and globulin.
Our results revealed that rams suffering from copper deficiency showed significant decrease in copper, selenium, zinc and iron. Copper deficiency induced decrease in iron absorption and release from body stores (Radostits, et al., 2000 and Tikoo, et al., 2018). Reduction of serum trace element as copper may be due to deficiency of trace elements in diet (Lazzaro, 2005). Our results are in accordence with Abdou, et al. (2010) and Eidi and Ghulam (2019) who stated that hypocuprosis rams showed reduction in zinc and iron. Hypocuprosis induced significant decrease in Testosterone, triiodothyronine and thyroxine. Copper deficiency produced significant decrease in testosterone (Massányi et al. 2003). Hypocuprosis reduced thyroid hormones Abdollahi, et al. (2013). Reduction in thyroid hormone may be due to impairment in the secretion of tyrosine hydroxylase and dopamine beta enzymes in hypothalamus (Yatoo, et al. 2013). Copper deficiency induced reducetion in T3 and $\mathrm{T} 4$ as copper is required for synthesis of phospholipids which are required for stimulation of thyroid stimulating hormone (Mohammed, et al., 2015)

Copper deficiency induced significant reduction in sperm cell number, motility and significant increase in dead sperm and total abnormal \% and insignificant reduction in ejaculate volume in rams. Hypocuprosis induced reduction in sperm number, motility, elevation in sperm abnormality and dead sperm due to inactivity of Sertoli cells induced by copper deficiency (Van Niekerk and Van Niekerk, 1989). Same findings were recorded by Gamik et al. al. (1990) who stated that copper deficiency induced significant reduction in sperm count and motility. Our results are agreed with Eidi, et al. (2010) who stated that hypocuprosis induce defective Spermatogenesis due to oxidative damage in testicular tissue. Disturbances in copper absorption induced negative impact on sperm viability (Knazicka et al., 2012). Hypocuprosis induced inferior sperm picture due to high levels of reactive oxygen species toxicity (Yatoo, et al., 2013). Copper induce improve sperm picture (Eva, et al., 2015).

Clinical signs were gradually disappeared beside hematobiochemical parameters and semen picture were ameliorated at $1^{\text {st }}$ day post treatment with copper sulphate. The same results were recorded by Church and Pond (1988) observed that supplementation mineral mixture to copper deficiency dairy goats improved hematobiochemical parameters. Semen quality and testosterone hormone in rams was improved post using copper (Abd El-Rahman, et al., 2000). Our results were supported by Lazzaro (2005) stated that treatment heifers suffering from copper deficiency by copper in ration induce improvement in hematobiochemical parameters. Copper induced increase in serum globulin levels in lambs due to increase in gamma globulin beside improve blood picture (Dezfoulian, et al., 2012).

Finally, it could be concluded that copper deficiency in rams affects male fertility (sperm count, motility, dead sperm, total abnormal\% and ejaculate volume) and hematobiochemical parameters, copper sulphate effective in ameliorating the adverse effects of copper deficiency in rams.

\footnotetext{
* Corresponding author Halla A. El Said. Biochemistry Department, Animal Health Research Institute - Zagazig Branch,

Egypt.E-mail address: hallaelsaid@yahoo.com
} 


\section{REFERENCES}

1. Abd Elghany, H. and El-khaiat, H. M. (2015): Importance of copper and effects of its deficiency and toxicity in animal. Inter. J of Lives Res 5(12) 73-88

2. Abd El-Rahman, H; El-Belely, M; Al-Qarawi, A. and ElMougy, S (2000) relation-ship between semen quality and mineral composition of semen in various ram breeds. Small Rumin Res., 1; 38(1):45-49

3. Abdollahi E.; Kohram, H. and Shahir, H. (2013): Plasma concentrations of essential trace microminerals and thyroid hormones during single or twin pregnancies in fat-tailed ewes. Small Ruminant Res., 113, 360-364.

4. Abdou, I.; Hussien, E.; Shadia, A. and El-Bakhmy, A. (2010): Hematological and clinical studies on trace elements profile in serum of unthrifty rams with a trial of treatment with uccmaphos. $10^{\text {th }}$ Sci.Vet. Med. Zag. Conference.418-425

5. Abraham, G. (1981): In clinical Endocrinology, Marcel Dokker, Inc. N.Y.

6. Bearden, H. and Flaquary, J. (1980): Applied Animal Reproduction, Reston Pub .Co., Jnc. Reston, Virginia, P. 158-160.

7. Aphzal, M.; Mervyn, C. and Fayez, G. (2010) Parasitic infection in association with serum copper, phosphorus, and haematological values in sheep and goats of central trinidad. West Indian Veterinary J., 10 (2) 12-19

8. Cheah, Y. and Yang, W. (2011): Functions of essential nutrition for high quality spermatogenesis. Advances in Bioscience and Biotechnology, 2, 182-197.

9. Christopher, J. (1992): Treatment of mineral disorders in cattle. Cited in Vet. Clin. Of North America food Animal Practice 8 (1): 107-145.

10. Church, D. and Pond, W. (1988):"Basic animal nutrition and feeding" $3^{\text {rd }}$ Ed. John Wiley and Sons, New York, Chichester, Brisbane, Toronto.

11. Coles, E. (1986): Veterinary clinical pathology. $4^{\text {th }}$ Ed. W.B. Saunders Company, Philadelphia, London and Toronto, pp. 305- 326

12. Dezfoulian, A.; Aliarabi, H.; Zamani, P.; Bahari, A. and Fadayifar, A. (2012): Influence of different levels of copper on performance, blood parameters, nutrient digestibility and mineral balance in lambs. Livest Sci.147 (3):9-19.

13. Dosm, N.; Santos, J.; Sarkis, J. and Guerra L. (2006): "Epidemiological, clinical, etiological and histopatological evaluation of delayed enzootic ataxia outbreaks in kids and lambs," Ciencia Rural, vol. 36, no. 4, pp. 1207-1213,

14. Doumas, B.; Certor, R.; Peers, T. and Schafler, R. (1981) Candidate reference method for determination of total protein in serum. Clin. Chem.(27):1642-1643.

15. Doumas, B. and Biggs, H. (1972): Standard Methods of Clinical Chemistry. 7, Academic Press. New York. Pp 175-188.

16. Drupt, F. (1974) determination of albumin. Phar. Bio (9) 453-455

17. Eidi, M. and Ghulam, M. (2019) copper deficiency in ruminants in Pakistan. Matrix Science Medica 2(1) 1821

18. Eidi, M.; Karamu, E.; Omid, P.; Pouneh, S.; Reza, F. and Massih, B. (2010): Seminal plasma levels of copper and its relationship with seminal parameters. Archive J. of Reproductive Med. 8 (2) 60-65

19. Eva, T.; Rohan, P.; Suresh, C. and Ashok, A. (2015): effect of iron and copper in male reproduction. J Assist Reprod Genet. 32(1): 3-16

20. Faizal, A.; and Rajapakse, R. (2001) Prevalence of coccidian and gastrointestinal nematode infections in crosses bred goats in the dry areas of Sri Lanka. S Rum Res.; 40:233-8

21. Fouda, T.; Ibrahim, T. and Seleim, H. (2005): body condition and chronic weight loss in sheep and their economical impacts. $4^{\text {Th }}$ Int. 9 Sci. Conf., Mansoura
22. Gamik, P; Bre, J and Mesko, P (1990) Effect of experimental intoxication with copper on reproductive ability in rams. Reprod. J of Dom Animals J., 25, 235241

23. Ibrahim, M. (1996): Studies on trace elements deficiency in goats. M.V.SC. Thesis Vet. Med .Suez Canal University

24. Jain, N. (1986) Schalm's Veterinary Hematology $4^{\text {th }}$ ed. Lee and Febiger Philadelphia, U.S.A. 55-96

25. John, D. (1982): Clinical laboratory method for determination of alkaline phosphates. $9^{\text {th }}$ ed. Pp. 580581.

26. Knazicka, Z.; Tvrda, E. and Lukac, N. (2012): Dose and time dependent effect of copper on viability of bull spermatozoa. J. of Env. Sci. and Health. 49, 94-100.

27. Lazzaro, A.(2005): Basic information on copper deficiency in Dariy Goats in southern California Saanendoah Dairy goats Winchester / Temecula, California.

28. Marzec, U.; Kamiński, P. and Łakota, P. (2012): Influence of chemical elements on mammalian spermatozoa. Folia Biologica J., 58, 7-12.

29. Massányi, P.; Nad, P. and Toman, R. (2003) Concentration of copper in boar semen and relation to spermatozoa quality. J. of Envi Sci. and Health. 38. 43 51.

30. Mohammed, H.; Ismail, A. and Ahmed, S. (2015); Evaluation of copper and zinc among hyper and hypothyroidism patients. European Acad Res 3(5) 522 534

31. Moning, H. (1963): Helminths, arthropods and protozoa of domestic animals. English Language Book Society, London.

32. Naylor, J.; Kasari, T. and Blakley, B. (2015): Diagnosis of copper deficiency and effects of supplementation in beef cows Can. J. of vet Res. 63: 343 - 348 .

33. Ortolani, C.; Machado, E. and Sucupira, M. (2003) "Assessment of some clinical and laboratory variables for early diagnosis of cumulative copper poisoning in sheep," Veterinary and Human Toxicology, 45 (6) 289293 ,

34. Osman, M.; Aly, A. and El-Nahala, A.(1991)Effect of copper on performance and some metabolic profiles of grasing ewes. Egypt. J. Appl. Sci.6 (10)72-84.

35. Radostits, O.; Gay, C.; Blood, D. and Hinchliff, K. (2000): Veterinary medicine, A Text book of the diseases of cattle, sheep, pigs, goats and horses. $9^{\text {th }} \mathrm{ed}$ W.B. Saunders Company Ltd., London, pp. 1510-1533, 18199-1822.

36. Radostits, O.; Gay, C.; Blood, D. and Hinchcliff, K. (2003): Veterinary med, A textbook of disease of cattle, sheep and horses. $10^{\text {th }}$ ed., WB Saunders, Canada.

37. Ralph, A. and McArdle, H. (2001): Copper metabolism and requirements in the pregnant mother, her fetus, and children. . New York: Inter Copper Association.

38. Reitman, S. and Frankel, S.(1957): Colorimetric determination of SGot and SGpt activity. Am. J. Clin. Path. (28) $56-59$.

39. Schwan, O.; Adrian, F. and Petersson, L. (1987) Cobalt and Copper Deficiency in Swedish Landrace Pelt Sheep. J. of Vet. Med. Series A (3) 231-239

40. Shahin, I. (2012) impairment of endocrine and exocrine pancreatic functions in copper-deficient rats and the amelioration role of aminoguanidine or/and nacetylcysteine. J. of American Sci. 8(1):581-590.

41. Soulsby,J. (1982): Helminths Arthropods and Protozoa of Domesticated Animal. $7^{\text {th }} \mathrm{Ed}$. The English Language Book society and Bailiare Tindall, London

42. Sunderman, F. and Roszel, N. (1967): Measurement of copper in biological materials by atomic absorption spectrometry. Am. J.Clin. Pathol. 48: 286

43. Tambane and Dunlop (2000): Statistics and Data Analysis from Elementary to Intermediate. Prentic Hall Ajitc. Tampbne Dorothy Dunlop, 2000. 
44. Tikoo, J.; Sodan, S. and Singh, R. (2018) Hematobiochemical Alterations in Calves born from Copper Supplemented Dams. Ntas Polivet 19 (2) 222225.

45. Tvrdá, E.; Peter, S.; Jana, L. and Norbert, L. (2013): Mineral nutrients and male fertility. J. of Microbiology, Biotechnology and Food Sci. 3 (1) 1-14

46. Van Niekerk, F. and Van Niekerk, H. (1989): influence of experimentally induced copper deficiency on the fertility of rams I. Semen parameters and peripheral plasma androgen concentration. J S Afr Vet Assoc.;60:28-31.

47. Waller, P. and Thamsborg, S. (2004) Nematode control in "green" ruminant production systems. Trends in Parasitology, 20(10), 493-497.

48. Yatoo, M.; Saxena, A.; Deepa, P.; Habeab, B. and Devi, S. (2013): Role of Trace elements in animals: a review. Vet. World 6, 963-967. 